\title{
Effects and Therapeutic Potentials of Kisspeptin Analogs: Regulation of the Hypothalamic-Pituitary-Gonadal Axis
}

\author{
Hisanori Matsui ${ }^{a}$ Taiji Asami $^{\text {b }}$ \\ ${ }^{\mathrm{a}}$ Extra Value Generation and General Medicine Drug Discovery Unit and ${ }^{\mathrm{b}}$ Medicinal Chemistry Research \\ Laboratories, Pharmaceutical Research Division, Takeda Pharmaceutical Company Limited, Fujisawa, Japan
}

\section{Key Words}

Kisspeptin $\cdot$ KISS1R $\cdot$ Kisspeptin analog $\cdot$ Testosterone $\cdot$

Desensitization

\begin{abstract}
The hypothalamic peptide kisspeptin (metastin), the endogenous ligand of the $G$ protein-coupled receptor KISS1R, plays a critical role in controlling $\mathrm{GnRH}$ release from hypothalamic $\mathrm{GnRH}$ neurons and thereby regulates hypothalamic-pituitary-gonadal functions. Although the therapeutic potential of kisspeptin is attractive, its susceptibility to proteolytic degradation limits its utility. To overcome this, KISS1R agonists or antagonists as peptide analogs or small molecules have been investigated. Kisspeptin analogs have been most extensively studied by reducing the length of the peptide from the original 54 amino acids to 10 amino acids or less and by substituting key amino acid residues. Also, 2 investigational kisspeptin agonist analogs have been evaluated in clinical studies in men; in agreement with animal studies, abrupt elevations in gonadotropin and testosterone levels were observed as an acute effect, followed by rapid reductions in these hormones as a chronic effect. Some studies of small-molecule KISS1R antagonists have also been pub-
\end{abstract}

\section{KARGER}

(c) 2014 S. Karger AG, Base

0028-3835/14/0991-0049\$39.50/0

E-Mail karger@karger.com

www.karger.com/nen lished. In this review, we present a brief overview on kisspeptin/KISS1R physiology in reproductive functions and summarize the available knowledge of both agonists and antagonists. We also focus on the kisspeptin agonist analogs by summarizing key pharmacological findings from both clinical and preclinical studies, and discuss their potential therapeutic utility.

(c) 2014 S. Karger AG, Basel

\section{Introduction}

Kisspeptin (Kp) is encoded by the KISS1 gene and is a peptide ligand of the $G$ protein-coupled receptor KISS1R (GPR54) [1-3]. The physiological roles of the Kp/KISS1R system in mammalian reproductive functions were first demonstrated in 2003-2004. Defective onset of puberty was observed to be associated with mutation of KISS1R in humans or deletion of Kiss1r in mice [4-6]. Moreover, central or peripheral Kp administration to several mammalian species, including humans, induced robust release of GnRH and gonadotropin [7-12]. Subsequent studies have revealed that GnRH neurons express Kiss $1 r$ mRNA and are depolarized by Kp exposure in vitro [13-15], sug- 
gesting that $\mathrm{Kp}$ directly regulates $\mathrm{GnRH}$ neurons. Anatomical investigations, most extensively in rodents, have revealed two populations of Kp neurons: one is within the arcuate nucleus (ARC) close to the median eminence and the other is around the anterior hypothalamic region, especially in the anteroventral periventricular nucleus (AVPV) [16-18]. In rodents, ARC Kp neurons are common to both males and females, and Kiss 1 mRNA expression is negatively regulated by steroid hormones [16-19]. In contrast, AVPV Kp neurons clearly show sexual dimorphism and are abundant in females, and Kiss $1 \mathrm{mRNA}$ expression is positively regulated by estradiol [16-18]. Recent findings strongly suggest that ARC Kp neurons are critical for GnRH pulses [20-24], whereas AVPV Kp neurons regulate preovulatory $\mathrm{GnRH} / \mathrm{LH}$ surges $[18,19$, $25]$. Although anatomical differences have been observed across species (detailed discussion of the neuroanatomy of kisspeptin system in human is present in this special issue by Hrabovszky [26]), it is now widely accepted that $\mathrm{Kp}$ plays a pivotal role in regulating both GnRH pulses and surges in mammals [27]. Although $\mathrm{Kp}$ acts within the hypothalamus, several studies showed that peripheral Kp administration can stimulate GnRH neurons [7, 9-12], presumably via circumventricular organs such as median eminence or the organum vasculosum of the lamina terminalis [28-30], thus offering attractive therapeutic targets.

The KISS1 gene produces a 145-amino-acid polypeptide, which is then enzymatically processed into $\mathrm{Kp}$ 54, a C-terminally amidated 54-amino-acid peptide [13]. Ohtaki et al. [1] evaluated agonistic and receptorbinding activities of several $\mathrm{N}$-terminal truncated peptides in vitro by $\left[\mathrm{Ca}^{2+}\right]_{i}$ mobilization assays using human KISS1R-expressing $\mathrm{CHO}$ cells and competitive binding analyses using membrane fractions prepared from the $\mathrm{CHO}$ cells, respectively, and revealed that the C-terminal 10-amino acid peptide Kp-10, $\mathrm{Tyr}^{45}-\mathrm{Asn}^{46}{ }_{-}$ $\mathrm{Trp}^{47}-\mathrm{Asn}^{48}-\mathrm{Ser}^{49}-\mathrm{Phe}^{50}-\mathrm{Gly}^{51}-\mathrm{Leu}^{52}-\mathrm{Arg}^{53}-\mathrm{Phe}^{54}-\mathrm{NH}_{2}$ (the superscripted numbers indicate the position of the amino acid residues based on $\mathrm{Kp}$-54), has 3 - to 10 -fold more potent in vitro agonistic and receptor-binding activity than the Kp-54 against human KISS1R [1]. This 10 -amino-acid sequence is well conserved among several species, including nonhuman primates, rodents, domestic animals, frogs and fish; in most mammals, except for primates, the RY-amide structure rather than the RF-amide structure has been identified (table 1). Although Kp10 administration induces gonadotropin release in vivo, its susceptibility to enzyme cleavage potentially limits its utility [31].

\section{KISS1R Agonists}

Both peptide and small-molecule approaches have been studied. Kuohung et al. [32] established a highthroughput screening system to evaluate both small-molecule agonists and antagonists and identified a potential agonist for KISS1R out of 110,000 compounds screened. However, its in vitro $\mathrm{EC}_{50}$ value is more than $0.1 \mathrm{mM}$ and the GnRH-releasing activity in vivo remains to be confirmed. On the other hand, short-form peptide agonist analogs of Kp-10 have been reported by us and other investigators [31, 33-35].

\section{Kp Agonist Analogs with Improved Biological Stability and Potency}

We initially found that more than $50 \%$ of $\mathrm{Kp}-10$ was rapidly metabolized in mouse serum within $1 \mathrm{~min}$, and using high-performance liquid chromatography/electrospray ionization mass spectrometry coupling experiments, we found two major peptide fragments predominating because of cleavage of $\mathrm{Tyr}^{45}-\mathrm{Asn}^{46}$ and $\mathrm{Arg}^{53}$ $\mathrm{Phe}^{54}$ by serum proteases, respectively [31].

\section{$\mathrm{Arg}^{53}-\mathrm{Phe}^{54}$}

Arg-containing peptides are well-known substrates for trypsin-like proteases [36-38], although the substitution of $\mathrm{Arg}^{53}$ with natural amino acids such as L-Ala or L-Leu or the corresponding D-amino acid D-Arg decreased in vitro agonistic activity [31]. Therefore, guanidino- $N$-alkyl ( $N^{\omega}$-alkyl) arginine derivatives, which retain the positive charge of Arg and exhibit various lipophilic and electrostatic characteristics, were then evaluated by substituting $\mathrm{Arg}^{53}$. These experiments indicated that the $N^{\omega}$-methylarginine analog showed 3-fold more potent in vitro agonistic activity in $\left[\mathrm{Ca}^{2+}\right]_{\mathrm{i}}$ mobilization assays than $\mathrm{Kp}-10$, with resistance to trypsin cleavage between positions 53 and 54 [31].

$$
T y r^{45}-A s n^{46}
$$

It is widely recognized that incorporation of $\mathrm{D}$-amino acids improves the biological potencies of peptides by altering conformational properties and increasing the resistance to enzymatic degradation $[37,38]$. Indeed, Kp-10 derivatives with $\mathrm{D}-\mathrm{Tyr}^{45}$ showed acceptable activity and evaded $\mathrm{N}$-terminal degradation, and the residual ratio of an analog with $\mathrm{D}$ - $\mathrm{Tyr}^{45}$ and $\operatorname{Arg}(\mathrm{Me})^{53}$ was highly improved to $18.1 \%$ after $1 \mathrm{~h}$ of incubation in mouse serum. However, several metabolites were still observed in the
Matsui/Asami 
Table 1. Alignment of putative Kp-10 amino acid sequences of KISS1 and KISS2 gene products

\begin{tabular}{|c|c|c|c|c|c|c|c|c|c|c|c|}
\hline \multirow[b]{2}{*}{ KISS1 gene product } & \multicolumn{10}{|c|}{ C-terminal 10 amino acid residues } & \multirow[t]{2}{*}{ GenBank No. } \\
\hline & & & & & & & & & & & \\
\hline Homo sapiens (human) & $\mathbf{Y}$ & $\mathbf{N}$ & $\mathrm{W}$ & $\mathbf{N}$ & S & $\mathbf{F}$ & G & $\mathbf{L}$ & $\mathbf{R}$ & $\mathrm{F}$ & AAC79512.1 \\
\hline Pan troglodytes (chimpanzee) & $\mathbf{Y}$ & $\mathbf{N}$ & $\mathrm{W}$ & $\mathbf{N}$ & S & $\mathbf{F}$ & G & $\mathbf{L}$ & $\mathbf{R}$ & $\mathrm{F}$ & AĀ05977.1 \\
\hline Gorilla gorilla gorilla (western lowland gorilla) & $\mathbf{Y}$ & $\mathbf{N}$ & $\mathrm{W}$ & $\mathbf{N}$ & $S$ & $\mathbf{F}$ & G & $\mathbf{L}$ & $\mathbf{R}$ & $\mathrm{F}$ & XP_004028270.1 \\
\hline Sus scrofa (pig) & $\mathbf{Y}$ & $\mathbf{N}$ & $\mathrm{W}$ & $\mathbf{N}$ & $S$ & $\mathbf{F}$ & G & $\mathbf{L}$ & $\mathbf{R}$ & $\mathrm{Y}$ & BĀ̄47553.1 \\
\hline Capra hircus (goat) & $\mathbf{Y}$ & $\mathbf{N}$ & $\mathrm{W}$ & $\mathbf{N}$ & S & $\mathbf{F}$ & G & $\mathbf{L}$ & $\mathbf{R}$ & $\mathrm{Y}$ & BAH89066.1 \\
\hline Ovis aries (sheep) & $\mathbf{Y}$ & $\mathbf{N}$ & $\mathrm{W}$ & $\mathbf{N}$ & $S$ & $\mathbf{F}$ & G & $\mathbf{L}$ & $\mathbf{R}$ & $\mathrm{Y}$ & AFW03832.1 \\
\hline Felis catus (domestic cat) & $\mathbf{Y}$ & $\mathbf{N}$ & $\mathrm{W}$ & $\mathbf{N}$ & S & $\mathbf{F}$ & G & $\mathbf{L}$ & $\mathbf{R}$ & $\mathrm{Y}$ & XP_003999526.1 \\
\hline Mus musculus (house mouse) & $\mathbf{Y}$ & $\mathbf{N}$ & W & $\mathbf{N}$ & $S$ & $\mathbf{F}$ & G & $\mathbf{L}$ & $\mathbf{R}$ & $\mathrm{Y}$ & BĀM11250 \\
\hline Rattus norvegicus (Norway rat) & $\mathbf{Y}$ & $\mathbf{N}$ & $\mathrm{W}$ & $\mathbf{N}$ & S & $\mathbf{F}$ & G & $\mathbf{L}$ & $\mathbf{R}$ & $\mathrm{Y}$ & EDM09773.1 \\
\hline Suncus murinus (house shrew) & $\mathbf{Y}$ & $\mathbf{N}$ & $\mathrm{R}$ & $\mathbf{N}$ & $S$ & $\mathbf{F}$ & G & $\mathbf{L}$ & $\mathbf{R}$ & $\mathrm{Y}$ & BAL02985.1 \\
\hline Cyprinus carpio (common carp) & $\mathbf{Y}$ & $\mathbf{N}$ & $\mathrm{L}$ & $\mathbf{N}$ & S & $\mathbf{F}$ & G & $\mathbf{L}$ & $\mathbf{R}$ & $\mathrm{Y}$ & AFM08413.1 \\
\hline Dicentrarchus labrax (European seabass) & $\mathbf{Y}$ & $\mathbf{N}$ & $\mathrm{L}$ & $\mathbf{N}$ & $S$ & $\mathbf{F}$ & G & $\mathbf{L}$ & $\mathbf{R}$ & $\mathrm{Y}$ & ACM07422.1 \\
\hline \multicolumn{12}{|l|}{ KISS2 gene product } \\
\hline Danio rerio (zebrafish) & $\mathbf{F}$ & $\mathbf{N}$ & $\mathrm{Y}$ & $\mathbf{N}$ & $\mathbf{P}$ & $\mathbf{F}$ & G & $\mathbf{L}$ & $\mathbf{R}$ & $\mathbf{F}$ & ACJ50541.1 \\
\hline Carassius auratus (goldfish) & $\mathbf{F}$ & $\mathbf{N}$ & $\mathrm{Y}$ & $\mathbf{N}$ & $\mathbf{P}$ & $\mathbf{F}$ & G & $\mathbf{L}$ & $\mathbf{R}$ & $\mathbf{F}$ & ACS34769.1 \\
\hline Oryzias latipes (Japanese medaka) & $\mathbf{F}$ & $\mathbf{N}$ & $\mathrm{Y}$ & $\mathbf{N}$ & $\mathbf{P}$ & $\mathbf{F}$ & G & $\mathbf{L}$ & $\mathbf{R}$ & $\mathbf{F}$ & BAG86623.1 \\
\hline Cyprinus carpio (common carp) & $\mathbf{F}$ & $\mathbf{N}$ & $\mathrm{Y}$ & $\mathbf{N}$ & $\mathbf{P}$ & $\mathbf{F}$ & G & $\mathbf{L}$ & $\mathbf{R}$ & $\mathbf{F}$ & AFM08414.1 \\
\hline Dicentrarchus labrax (European seabass) & $\mathbf{F}$ & $\mathbf{N}$ & $\mathrm{F}$ & $\mathbf{N}$ & $\mathbf{P}$ & $\mathbf{F}$ & G & $\mathbf{L}$ & $\mathbf{R}$ & $\mathbf{F}$ & ACM07423.1 \\
\hline
\end{tabular}

electrospray ionization mass spectrometry spectra, including products of cleavage between $\mathrm{Trp}^{47}-\mathrm{Asn}^{48}$, $\mathrm{Phe}^{50}$ $\mathrm{Gly}^{51}$, and $\mathrm{Gly}^{51}-\mathrm{Leu}^{52}[33]$.

$$
\text { Phe } e^{50}-G l y^{51} \text { and } G l y^{51}-L^{2} u^{52}
$$

$\mathrm{Kp}$ analogs with $\mathrm{D}$-amino acid substitutions at residues $\mathrm{Phe}^{50}$-Gly ${ }^{51}$ showed improved metabolic stability but reduced in vitro agonistic activity. Pseudopeptides have become important for medicinal chemistry. For example, Kp analogs with 5 -amino-acid residues containing $(E)$-alkene and hydroxyethylene-type isosteres showed high stability in mouse serum [34]. In our study, other simple pseudopeptides including azapeptides at residues $\mathrm{Phe}^{50}-\mathrm{Gly}^{51}$ without altering the side chain moieties were then tested. The replacement of Gly ${ }^{51}$ with an azaGly residue, which involved a simple nitrogen atom replacement of the a-carbon on Gly ${ }^{51}$, improved KISS1R agonistic activity, presumably because of the change in the overall conformation of peptide analogs, thus avoiding enzymatic degradation [33]. This indicated that some $\beta$-turn conformations, which are reportedly observed in azapeptides [39-41], may contribute to interactions with KISS1R. Moreover, incorporation of the azaGly ${ }^{51}$ residue improved metabolic stability of Phe ${ }^{50}$-Gly ${ }^{51}$ and $\mathrm{Gly}^{51}$-Leu ${ }^{52}$ bonds, which were resistant to serum proteases such as chymotrypsin, neutral endopeptidases and matrix metalloproteinase-9 [33].

\section{$\operatorname{Tr} p^{47}-A s n^{48}$}

Substitution of $\operatorname{Trp}{ }^{47}$ with other amino acids such as serine, threonine, $\beta$-(3-pyridyl)alanine or D-tryptophan (D-Trp), produced several azaGly ${ }^{51}$ analogs that were resistant to metabolic degradation after $1 \mathrm{~h}$ of incubation in mouse serum. The replacement of key amino acids with azaGly ${ }^{51}$ resulted in metabolically stable analogs that could be easily synthesized using solid-phase methods without preparing dipeptide isostere units. Among these, the D-Trp ${ }^{47}$ analog showed not only high metabolic stability but also excellent KISS1R agonistic activity (fig. 1), although other analogs showed decreased agonistic activities compared with Kp-10 [31, 33]. 
Fig. 1. Summary of optimization results: a biological stable lead peptide KISS1-305 with high agonistic activity was obtained from 5 amino acid substitutions of Kp-10.

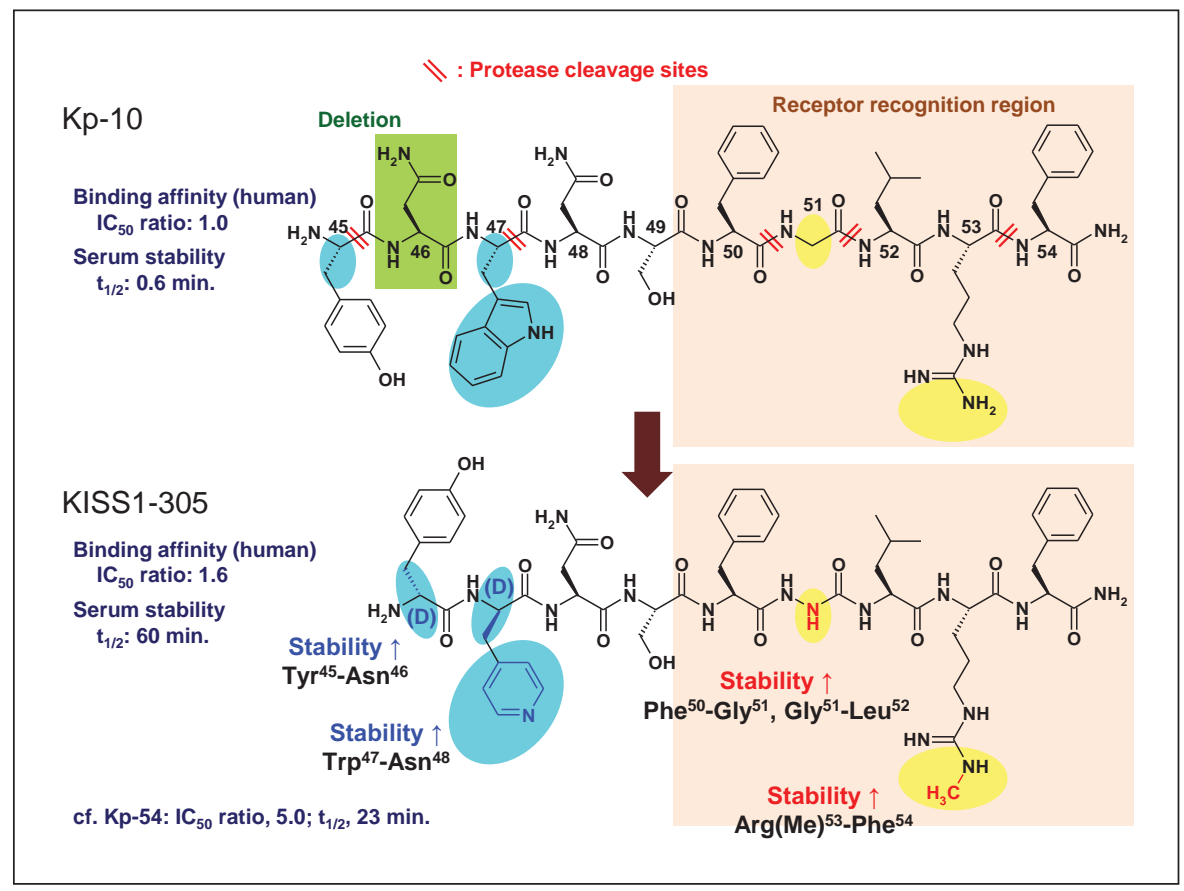

Table 2. Representative Kp agonist analogs

\begin{tabular}{|c|c|c|c|c|c|c|c|c|c|c|c|c|}
\hline Peptide & & \multicolumn{11}{|c|}{ Position } \\
\hline KISS1-305 & & D-Tyr & & D-Pya (4) & Asn & Ser & Phe & azaGly & Leu & $\operatorname{Arg}(\mathrm{Me})$ & Phe & $\mathrm{NH}_{2}$ \\
\hline TAK-448 & Ac & D-Tyr & & Нyp & Asn & Thr & Phe & azaGly & Leu & $\operatorname{Arg}(\mathrm{Me})$ & Trp & $\mathrm{NH}_{2}$ \\
\hline TAK-683 & Ac & D-Tyr & & D-Trp & Asn & Thr & Phe & azaGly & Leu & $\operatorname{Arg}(\mathrm{Me})$ & Trp & $\mathrm{NH}_{2}$ \\
\hline
\end{tabular}

\section{KISS1-305, TAK-448 and TAK-683}

In order to identify Kp agonist analogs with improved metabolic stability and enhanced potency in vivo, a series of $\mathrm{Kp}-10$ analogs containing 3 key replacements, Nterminal D-Tyr, azaGly ${ }^{51}$ and $\operatorname{Arg}(\mathrm{Me})^{53}$, were synthesized and studied in vitro and in vivo. In addition to the substitutions mentioned above, deletion of $\mathrm{Asn}^{46}$ to avoid inactivation of the peptide through chemical isomerization and substitution of $\operatorname{Trp}^{47}$ produced highly potent and long-acting analogs suitable for in vivo study. Positions 45-47 were considered to be flexible for receptor recognition. This was supported by data showing that modifications at positions $\operatorname{Tyr}^{45}-\operatorname{Trp}^{47}$ of nonapeptide analogs resulted in small decreases in biological activity [35]. These experiments demonstrated that both agonistic activity and metabolic stability were important for the performance of these peptides. Thus, the biologically stable agonist analog KISS1-305, D-Tyr ${ }^{46}$-DPya $(4)^{47}-$ Asn $^{48}-$ Ser $^{49}-$ Phe $^{50}$-azaGly ${ }^{51}-$ Leu $^{52}$-Arg $(\mathrm{Me})^{53}$ $\mathrm{Phe}^{54}-\mathrm{NH}_{2}$ was identified [35] (fig. 1), and subsequent studies eventually led to the identification of the 2 investigational $\mathrm{Kp}$ agonist analogs TAK-448 and TAK-683 [35] (table 2).

\section{Acute Effects of Kp or Its Agonist Analogs on Reproductive Functions}

Because $\mathrm{Kp}$ is critical for GnRH physiology, two possible approaches were considered as therapeutic targets. The first was the improvement or stimulation of the reproductive functions by inducing $\mathrm{GnRH}$ release from 
the hypothalamus, which can potentially be used to treat conditions such as hypogonadism, infertility and anovulation. The second was the suppression of the reproductive functions, allowing treatment of hormone-dependent diseases such as prostate cancer, benign prostate hyperplasia, endometriosis and breast cancer. As mentioned above, abrupt elevations of FSH/LH levels have been observed in several species as an acute effect. The first human study with $\mathrm{Kp}$ was conducted by Dhillo et al. [10], who administered 90-min intravenous infusions of Kp-54 (0.125-40 pmol/ $\mathrm{kg} / \mathrm{min})$ in men. This treatment resulted in dose-dependent elevations in plasma FSH/LH levels and caused a slight elevation in testosterone levels. George et al. [12] demonstrated that intravenous bolus administration of $\mathrm{Kp}-10$ in healthy men dose-dependently elevated plasma LH and FSH levels up to $1 \mu \mathrm{g} / \mathrm{kg}$. However, the administration of $3 \mu \mathrm{g} / \mathrm{kg}$ of $\mathrm{Kp}-10$ failed to elicit a statistically significant increase in LH and FSH levels; the underlying mechanisms remain unclear. Chan et al. [11] investigated the effects of intravenous injections of $\mathrm{Kp}-10(0.24 \mathrm{nmol} / \mathrm{kg})$ in men and observed not only elevated gonadotropin levels but also a possibility of resetting the $\mathrm{GnRH} / \mathrm{LH}$ pulse clock. The acute effects of TAK-683 (0.01-2 mg/man) were also investigated in healthy male volunteers [42]. In this study, plasma gonadotropin levels peaked at $8 \mathrm{~h}$, followed by an increase in plasma testosterone levels at $16-48 \mathrm{~h}$ after dosing.

The metabolic state is known to affect hypothalamic functions, and obesity and type 2 diabetes mellitus (T2DM) are frequently associated with hypogonadism [43, 44]. George et al. [45] demonstrated that the administration of a single bolus of $\mathrm{Kp}-10$ in hypotestosteronemic men with T2DM induced LH elevations comparable with those in normal healthy men, suggesting that $\mathrm{GnRH}$ neurons maintain responsiveness to Kp stimuli in hypotestosteronemic patients with T2DM. This finding is in accordance with the results of previous animal studies in diabetic models [46-48]. In women, responsiveness to Kp varied across menstrual cycles; the most apparent LH elevations may be associated with increased LH pulsatility that occurred during the late follicular phase, which is the preovulatory phase, whereas attenuated responsiveness was observed during the early follicular phase [49-52]. Similar estrous cycle dependence has also been reported in female rats [53]. One potential explanation for these variable responses, including sexual dimorphism, is the differences in the sex steroid hormone milieu as recently suggested by George et al. [54]; however, the precise mechanisms remain unknown.

Manipulation of the HPG Axis Using

Kisspeptin and its Analogs

\section{Chronic Effects of Kp or Its Agonist Analogs on Reproductive Functions}

It is widely known that continuous exposure to hormones or drugs leads to desensitization or tachyphylaxis, and one of the most famous examples is the suppression of gonadal functions by the continuous administration of GnRH or its agonist analogs, demonstrating that pulsatile GnRH release is critical in order to maintain pituitary function [55-57]. Pulsatile Kp release has been also proposed [24], and several studies have shown that continuous $\mathrm{Kp}$ administration also results in desensitization/ tachyphylaxis of hypothalamic-pituitary-gonadal (HPG) functions in rats, monkeys and women with hypothalamic amenorrhea [58-62]. We have also evaluated the effects of continuous administration of $\mathrm{Kp}$ agonist analogs in male rats, monkeys and dogs and demonstrated rapid and profound testosterone suppression $[63,64]$. These studies essentially showed similar outcomes: initiation of chronic dosing primarily induces abrupt elevation in gonadotropin/testosterone levels, followed by a rapid decline in gonadotropin/testosterone release. In contrast, differences have been observed between natural Kp and Kp agonist analogs. Specifically, Kp agonist analogs more profoundly suppressed testosterone levels in rats and monkeys than natural Kp [58, 61-64]. Moreover, Seminara et al. [59] showed that NMDA induced gonadotropin release in monkeys after continuous Kp-10 treatments, suggesting the preservation of GnRH-releasing ability of the GnRH neurons, whereas in our study LH was not elevated by NMDA after continuous KISS1-305 administration to male rats [63]. Although species differences should be considerable, these results may reflect differences in biological potency between Kp-10 and Kp agonist analogs. Accordingly, phase I clinical studies have been completed showing that subcutaneous infusion of TAK-448 (0.01-1 $\mathrm{mg} / \mathrm{man} /$ day $)$ and TAK-683 (0.01-2 mg/man/day) for 2 weeks in healthy male volunteers rapidly but reversibly reduced testosterone levels in a dose-dependent manner $[42,65]$.

In contrast, George et al. [12] showed that continuous subcutaneous infusion of $\mathrm{Kp}-10(4 \mu \mathrm{g} / \mathrm{kg} / \mathrm{h})$ for $22.5 \mathrm{~h}$ in healthy men increased plasma LH levels throughout the infusion period, without apparent desensitization. Moreover, 11-hour infusions of Kp-10 at the same dose in hypotestosteronemic men with T2DM led to successful elevations in LH and testosterone levels [45]. The lack of apparent desensitization in these studies may be attributed to shorter dosing durations. Jayasena et al. [61, 62] investigated the effects of repeated subcutaneous dosing 


\begin{tabular}{|l|c|c|}
\hline $\begin{array}{l}\text { GnRH neural } \\
\text { response }\end{array}$ & ORX & TAK-448 \\
\hline Gnrh mRNA & Unchanged & $\begin{array}{c}\text { Attenuated } \\
\text { (desensitization) }\end{array}$ \\
\hline GnRH peptide & Gradual decrease & Rapid decrease \\
\hline $\begin{array}{l}\text { Pituitary } \\
\text { response }\end{array}$ & Responsive* & Responsive \\
\hline Fshb/Lhb mRNA & Increase & Decrease \\
\hline FSH/LH protein & Increase & Gradual decrease \\
\hline Plasma FSH/LH & Increase & Decrease \\
\hline Plasma T & Decrease & Decrease \\
\hline
\end{tabular}

Fig. 2. Summary of the status of the HPG axis under continuous administration of $\mathrm{Kp}$ analogs in comparison with ORX in male rats. Each description represents the changes from the vehicle control based on the results described in [42]. For example, Gnrh mRNA expression levels were unchanged regardless of the treatment, whereas hypothalamic GnRH contents were gradually (ORX) or rapidly reduced (Kp analog treatment). Items with asterisks are presumable (and not confirmed in [42]).

of $\mathrm{Kp}-54(6.4 \mathrm{nmol} / \mathrm{kg})$ in normal healthy women and women with hypothalamic amenorrhea. In the latter, twice-daily injections of $\mathrm{Kp}-54$ eventually resulted in desensitization to exogenous $\mathrm{Kp}-54$, while twice-weekly dosing of Kp-54 avoided the desensitization. In contrast, in healthy women, twice-daily administration of Kp-54 for a week did not cause desensitization, and their menstrual cycles were preserved [66]. As mentioned above, differences in the sex steroid hormone milieu may explain the differences, although more detailed pathophysiological studies are required for more precise explanations.

\section{Continuous Administration of Kp or Kp Agonist Analogs and Suppression of HPG Function: Mechanism of Action}

\section{Suppression of GnRH Release by Chronic}

Administration of Kp or Kp Agonist Analogs

Under continuous administration of Kp or Kp agonist analogs associated with lowering of LH/testosterone lev- els, bolus $\mathrm{Kp} / \mathrm{Kp}$ agonist analogs cannot induce $\mathrm{LH}$ release [58-60, 63]. However, our studies and others showed that single bolus administration of GnRH or its agonist analogs induces LH release [59, 63] (fig. 2), suggesting that the continuous administration of $\mathrm{Kp} / \mathrm{Kp}$ agonist analogs does not desensitize the pituitary but suppresses GnRH release. In fact, Ohkura et al. [67] showed suppression of GnRH pulses in goats treated continuously with TAK-683. We also observed marked suppression of pituitary $F s h b / L h b$ mRNA and protein expression after continuous administration of Kp agonist analogs [63] (fig. 2), supporting a mechanism involving the suppression of GnRH pulses. This may be associated with attenuated but not desensitized responsiveness of the pituitary to $\mathrm{GnRH}$, particularly after long-term treatment with $\mathrm{Kp}$ agonist analogs.

\section{Desensitization of GnRH Neurons}

In goats, continuous treatment with TAK-683 suppressed GnRH pulses as stated above, although the animals maintained multiple unit activity (MUA) volleys [68], which are thought to be a consequence of $\mathrm{GnRH}$ pulse generator activities within the mediobasal hypothalamus, and recent studies have suggested that ARC Kp neurons are possible sources of this electrical activity $[21,22]$. Thus, under the continuous administration of TAK-683 it is plausible that GnRH neurons become insensitive to endogenous $\mathrm{Kp}$ pulses. Investigations in mouse GnRH neurons and KISS1R-expressing $\mathrm{CHO}$ cells suggest that KISS1R desensitization occurs within $12 \mathrm{~h}$. A potential mechanism of KISS1R desensitization may involve receptor internalization and subsequent reduction in cell surface KISS1R, uncoupling to G proteins, altered downstream signaling, or ubiquitination $[69,70]$. In in vivo experiments, continuous Kp-10 infusion in monkeys induced abrupt elevations in LH levels for a few hours [59]. In male rats, continuously administered Kp54 elevated plasma LH levels both at 6 and $12 \mathrm{~h}$ after initiation of continuous dosing, although the LH levels almost returned to the baseline level at $24 \mathrm{~h}$ [58]. We observed similar LH-releasing profiles after continuous subcutaneous administration of $\mathrm{Kp}$ agonist analogs to adult male rats, which led to marked LH release and apparent c-Fos expression within GnRH neurons at 4 and $8 \mathrm{~h}$. However, LH release declined and c-Fos expression disappeared within $24 \mathrm{~h}$ [63]. Taken together, these data suggest that continuous administration of Kp or its agonist analogs rapidly desensitizes KISS1R both in vitro and in vivo. 
Fig.3. Schematic illustration of hypothalamic GnRH/KNDy neurons and effects of KISS1R agonists/antagonists on pulsatile $\mathrm{GnRH} / \mathrm{LH}$ release. Dyn = Dynorphin; POA $=$ preoptic area; $\mathrm{ME}=$ median eminence; $(+)=$ tonic effect; $(-)=$ inhibitory effect. a Normal state of hypothalamic $\mathrm{GnRH}$ neurons. To generate GnRH pulses, KNDy neurons presumably project to $\mathrm{GnRH}$ neural terminals and produce Kp pulses, which in turn lead to pulsatile GnRH release and eventually stimulate the pituitary. Although unknown, Kp-independent other neurons may support GnRH neural activity. b KISS1R antagonists (Kp-ant) block KISS1R on GnRH neural terminals, which in turn suppress GnRH release. KISS1R antagonists may not be able to suppress Kp-independent neural inputs; however, further studies are required for clarification. c KISS1R agonists (Kp-a) acutely stimulate $\mathrm{GnRH}$ release. Abrupt elevations in plasma LH levels were generally observed, whereas infusions of small quantities of Kp-10 may increase $\mathrm{GnRH} / \mathrm{LH}$ pulse frequencies without resulting in desensitization. d Continuous administration of KISS1R agonists paradoxically suppresses GnRH release, potentially because of desensitization of KISS1R on $\mathrm{GnRH}$ neural terminals. Studies of Kp agonist analogs in male rats also suggest small and nonpulsatile leakage of GnRH.

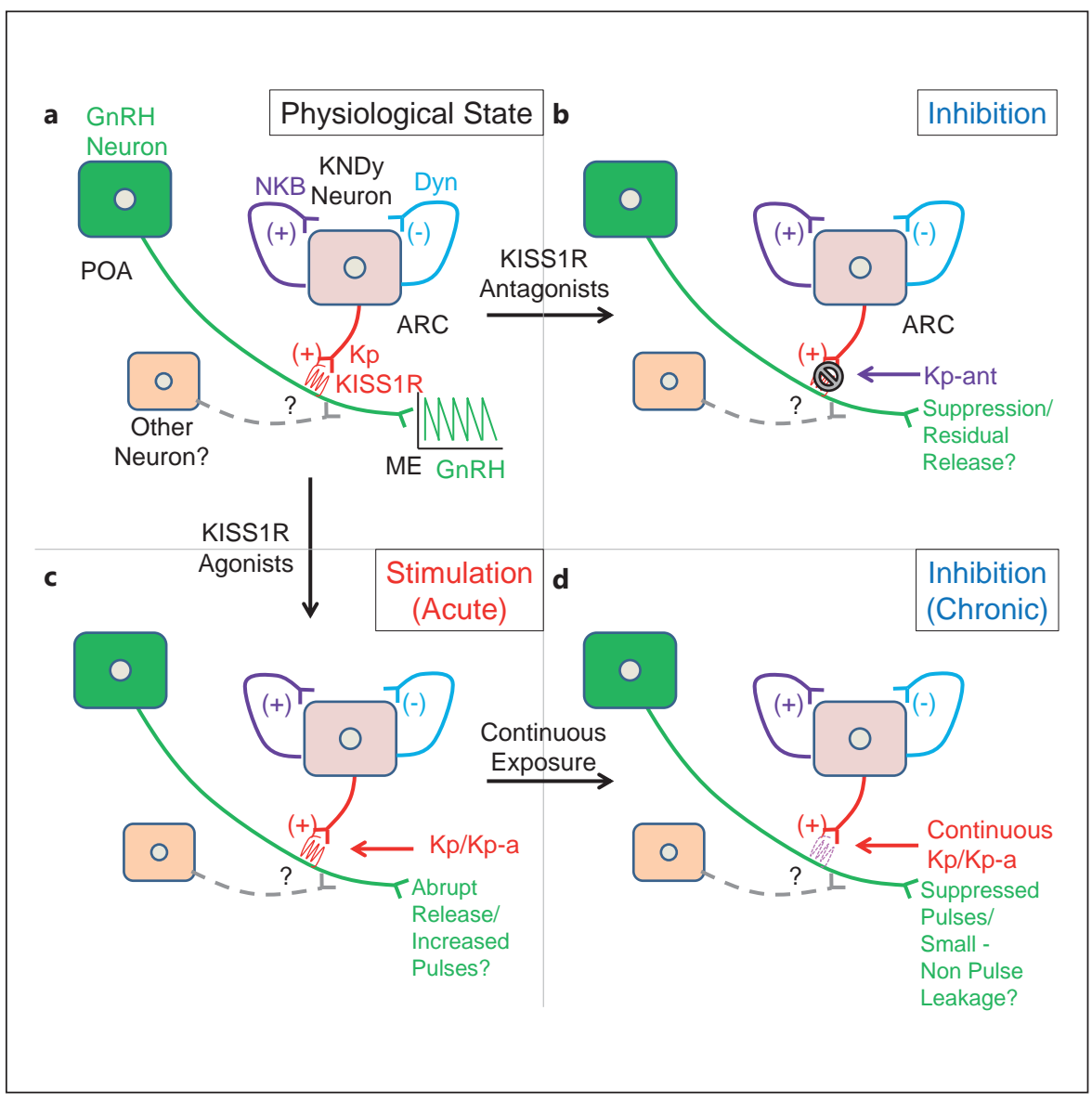

\section{Unrecovered Hypothalamic GnRH Contents}

Desensitization of GnRH neurons could precede complete loss of responsiveness to further Kp stimuli, but our study in male rats suggested that this is not the case. As mentioned above, continuous administration of Kp agonist analogs leads to rapid declines in c-Fos immunoreactivity in GnRH neurons. However, c-Fos immunoreactivity was again induced in the majority of $\mathrm{GnRH}$ neurons in response to a single high dose of $\mathrm{Kp}$ agonist analogs [63] (fig. 2). This observation suggests that GnRH neurons maintain responsiveness to high doses of Kp agonist analogs, at least in terms of c-Fos immunoreactivity induction; therefore, desensitization of GnRH neurons does not indicate 'complete abolishment of the responsiveness to Kp' but actually indicates 'significant attenuation of the responsiveness to Kp. Furthermore, hypothalamic GnRH peptide levels were rapidly and dramatically reduced. The GnRH content did not recover during the 4-week dosing period, although Gnrh mRNA expression remained unchanged (fig. 2), suggesting the involvement of a posttranslational mechanism. Bilateral orchiectomy (ORX) also dramatically reduced hypothalamic $\mathrm{GnRH}$ content without changing Gnrh mRNA expression, whereas pituitary gonadotropin expression and plasma gonadotropin levels were significantly increased $[63,71]$, presumably due to increased pulsatile GnRH release [72-74] (fig. 2). This contrasts with the Kp effects which differed in the reduction of gonadotropins. Decreased and unrecovered $\mathrm{GnRH}$ contents after continuous administration of Kp agonist analogs may reflect continuous release of $\mathrm{GnRH}$, but in this case we suggest low-level and nonpulsatile leakage, which is biologically insignificant for gonadotropin secretion but could prevent recovery of hypothalamic $\mathrm{GnRH}$ content (fig. 3) [63]. This hypothesis requires remaining KISS1R on the cell surface after chronic exposure to Kp agonist analogs, and it may be supported by previous findings suggesting intracellular KISS1R pools and dynamic receptor recycling even after chronic exposure to the ligand $[75,76]$. In addition, this continuous stimulation of $\mathrm{GnRH}$ neurons and subsequent nonpulsatile low-level leakage may disrupt $\mathrm{Kp}$-independent $\mathrm{GnRH}$ release as suggested by Chan et al. [77]. 


\section{KISS1R Antagonists}

Both peptide and small-molecule KISS1R antagonists have been reported, and their in vivo efficacy has been investigated. In 2009, Roseweir et al. [78] reported Kp antagonist analogs, and their work has been described in detail elsewhere [79]. In brief, Roseweir et al. [78] tried to identify key amino acid residues that were critical for in vitro receptor binding and antagonistic activity, while avoiding residual agonistic effects. Initially, they identified critical amino acid residues within the five $\mathrm{C}$-terminal amino acids using $\mathrm{N}$-terminally truncated peptides and revealed that a length of 10 amino acids is important for efficient receptor binding. They also found that the $\mathrm{C}$-terminal RFamide structure as well as $A s n^{46}, \operatorname{Trp}^{47}$ and $\mathrm{Phe}^{50}$ are critical for receptor binding. In contrast to Kp agonist analog studies, the substitution of $\mathrm{Phe}^{54}$ with $\operatorname{Trp}^{54}$ was not efficacious in their antagonist screening, whereas our Kp agonist analogs as well as those reported by Niida et al. [80] demonstrated that RW-amide structures result in good Kp agonist analogs [35]. In subsequent screening based on in vitro antagonist assays, Roseweir et al. [78] identified that replacements of Ser ${ }^{49}$ and Leu ${ }^{52}$ with D-amino acids or Gly ${ }^{49}$ and $\mathrm{D}-\operatorname{Trp}^{52}$ were the key for antagonism. They also demonstrated that $A s n^{46}-\operatorname{Trp}^{47}$ residues were important because deletions in these positions resulted in attenuated antagonistic activity. Thus, they identified 4 potential Kp antagonist analogs, and the peptide 234 with ac-[D-Ala ${ }^{45}$, Gly ${ }^{49}$, $\left.\mathrm{D}-\mathrm{Tr}^{52}\right] \mathrm{Kp}-10$ has been most extensively tested in several animals, showing the suppression of $\mathrm{GnRH} / \mathrm{LH}$ pulses in intact or gonadectomized animals, delay in vaginal opening or inhibition of preovulatory LH surges $[25,78,80,81]$. These findings are in accordance with previous data demonstrating that $\mathrm{Kp}$ regulates both steroid hormone negative (i.e. $\mathrm{GnRH}$ pulses) and positive (i.e. preovulatory surge) feedback effects as well as the onset of puberty [27].

Kobayashi et al. [82, 83] reported small-molecule antagonists of the KISS1R receptor, including 2-acylamino-4,6-diphenylpyridine derivatives. Of several derivatives, they evaluated the in vivo efficacy of compound $15 \mathrm{a}$ in castrated male rats and showed reduced plasma LH levels [83]. Although these KISS1R antagonists reduce gonadotropin levels, it appears that the suppression is marginal compared to more profound suppressions by continuous administration of $\mathrm{Kp}$ agonist analogs. One possible explanation may be insufficient drug exposure of $\mathrm{Kp}$ antagonists at the target site. Another possibility is that a Kp/KISS1R-independent mechanism may be involved in $\mathrm{GnRH} /$ gonadotropin release, which cannot be suppressed by Kp antagonists [77] (fig. 3).

\section{Future Perspectives and Potential Therapeutic Utility}

Following the discovery of the role of Kp in reproductive functions, numerous physiological and pharmacological effects of Kp have been delineated during the past decade, suggesting that KISS1R agonists and antagonists may provide novel treatment approaches to control HPG functions via stimulatory or inhibitory mechanisms of action. Notably, clinical studies with $\mathrm{Kp}$ or Kp agonist analogs have reported excellent safety [10-12, 42, 45, 49, 50, 65]. However, several effects remain uncharacterized to date, as mentioned above, such as the sexual dimorphic effects of $\mathrm{Kp}$ or the complex $\mathrm{Kp}$ responses in women. In addition, Tanaka et al. [84] recently demonstrated that the continuous administration of TAK-683 in ovariectomized goats suppressed LH pulses but induced surge-like LH release following estradiol infusion, as shown in control animals, suggesting that continuous exposure to Kp agonist analogs differentially affected pulsatile and surge mode secretions of $\mathrm{GnRH}$ and $\mathrm{LH}$ in female goats. Moreover, recent data strongly suggest that $\mathrm{Kp}$ neurons in ARC, which are responsible for receiving steroid hormone negative feedback, also express other neurotransmitters such as neurokinin $\mathrm{B}(\mathrm{NKB})$ and dynorphin, and these findings led us to describe ARC Kp neurons as KNDy neurons (Kp, NKB and dynorphin) [85-90]. We will not describe KNDy neurons in detail here; however, emerging data on KNDy neurons have provided important clues to the neural mechanisms of $\mathrm{GnRH}$ pulse generation systems (detailed review articles of the role of KNDy neurons are present in this special issue by Grachev et al. [91] and Goodman et al. [92]). In brief, KNDy neurons apparently express the NKB receptor (NK3R) [89, 93] and lack KISS1R $[21,94,95]$. The expression of the $\kappa$-opioid receptor (KOR) remains controversial [96]. On the other hand, GnRH neurons express KISS1R [13, 14], with little evidence regarding the expression of NK3R $[93,96]$ or KOR $[97,98]$. Human inactivating mutations in KISS1, KISS1R $N K B$, or $N K 3 R$ lead to severe hypogonadism and pubertal disorders $[4,5,99,100]$. In contrast, presumable gain-offunction mutations in KISS1 and KISS1R have been identified in patients with central precocious puberty [101, 102]. In animals, NKB and senktide (an NKB agonist), stimulate GnRH/LH secretion and activate KNDy neurons [96, 103-105], presumably leading to increased pulse frequency, as shown in MUA volley [103]. In contrast, endogenous opioids have been known to suppress $\mathrm{GnRH}$ secretion and recent evidence (e.g. in goats) suggests that dynorphin suppresses MUA volley, whereas the KOR an-
56 
tagonist norbinaltorphimine increases it [103]. Thus, a KNDy neuron model has been established; Kp serves as the stimulatory output from KNDy neurons to GnRH neurons, whereas KNDy neurons form KNDy-KNDy neural circuits to control their pulse-generating activity via tonic $\mathrm{NKB}$ and inhibitory dynorphin either directly or indirectly [85-90]. Notably, the effects of NKB or its agonists on LH secretion remain controversial, particularly in rodents, because some groups have demonstrated that NKB agonists suppress LH secretion [106, 107]. Interestingly, this effect also appears to be dynorphin-KOR dependent [104]. Therefore, agonists/antagonists of NK3R or KOR may also provide novel therapeutic approaches to precisely regulate the HPG axis in addition to the $\mathrm{Kp} /$
KISS1R system. Moreover, KNDy neurons may have other physiological roles such as thermoregulation [108]. Additional physiological and pharmacological studies will provide deeper knowledge of these neural systems and may eventually provide novel therapeutic approaches focused on the Kp/KISS1R system.

\section{Acknowledgments}

The authors thank Drs. Tetsuya Ohtaki, Masami Kusaka and Chieko Kitada for extensively supporting and encouraging these Kp studies. We also thank Dr. Kaori Ishikawa for editorial support, and thank Crimson Interactive Japan Co., Ltd. for English editing of this manuscript.

\section{References}

1 Ohtaki T, Shintani Y, Honda S, Matsumoto H, Hori A, Kanehashi K, Terao Y, Kumano S, Takatsu Y, Masuda Y, Ishibashi Y, Watanabe T, Asada M, Yamada T, Suenaga M, Kitada C, Usuki S, Kurokawa T, Onda H, Nishimura O, Fujino M: Metastasis suppressor gene KiSS-1 encodes peptide ligand of a G-protein-coupled receptor. Nature 2001;411:613-617.

- Kotani M, Detheux M, Vandenbogaerde A, Communi D, Vanderwinden JM, Le Poul E, Brezillon S, Tyldesley R, Suarez-Huerta N, Vandeput F, Blanpain C, Schiffmann SN, Vassart G, Parmentier M: The metastasis suppressor gene KiSS-1 encodes kisspeptins, the natural ligands of the orphan $\mathrm{G}$ protein-coupled receptor GPR54. J Biol Chem 2001;276: 34631-34636.

-3 Muir AI, Chamberlain L, Elshourbagy NA, Michalovich D, Moore DJ, Calamari A, Szekeres PG, Sarau HM, Chambers JK, Murdock P, Steplewski K, Shabon U, Miller JE, Middleton SE, Darker JG, Larminie CG, Wilson S, Bergsma DJ, Emson P, Faull R, Philpott KL, Harrison DC: AXOR12, a novel human G protein-coupled receptor, activated by the peptide KiSS-1. J Biol Chem 2001;276:2896928975.

-4 de Roux N, Genin E, Carel JC, Matsuda F, Chaussain JL, Milgrom E: Hypogonadotropic hypogonadism due to loss of function of the KiSS1-derived peptide receptor GPR54. Proc Natl Acad Sci USA 2003;100:10972-10976.

-5 Seminara SB, Messager S, Chatzidaki EE, Thresher RR, Acierno JS Jr, Shagoury JK, BoAbbas Y, Kuohung W, Schwinof KM, Hendrick AG, Zahn D, Dixon J, Kaiser UB, Slaugenhaupt SA, Gusella JF, O’Rahilly S, Carlton MB, Crowley WF Jr, Aparicio SA, Colledge $\mathrm{WH}$ : The GPR54 gene as a regulator of puberty. N Engl J Med 2003;349:1614-1627.

-6 Funes S, Hedrick JA, Vassileva G, Markowitz L, Abbondanzo S, Golovko A, Yang S, Monsma FJ, Gustafson EL: The KiSS-1 receptor
GPR54 is essential for the development of the murine reproductive system. Biochem Biophys Res Commun 2003;312:1357-1363.

-7 Matsui H, Takatsu Y, Kumano S, Matsumoto $\mathrm{H}$, Ohtaki T: Peripheral administration of metastin induces marked gonadotropin release and ovulation in the rat. Biochem Biophys Res Commun 2004;320:383-388.

8 Gottsch ML, Cunningham MJ, Smith JT, Popa SM, Acohido BV, Crowley WF, Seminara S, Clifton DK, Steiner RA: A role for kisspeptins in the regulation of gonadotropin secretion in the mouse. Endocrinology 2004; 145:4073-4077.

-9 Thompson EL, Patterson M, Murphy KG, Smith KL, Dhillo WS, Todd JF, Ghatei MA, Bloom SR: Central and peripheral administration of kisspeptin-10 stimulates the hypothalamic-pituitary-gonadal axis. J Neuroendocrinol 2004;16:850-858.

10 Dhillo WS, Chaudhri OB, Patterson M, Thompson EL, Murphy KG, Badman MK, McGowan BM, Amber V, Patel S, Ghatei MA, Bloom SR: Kisspeptin-54 stimulates the hypothalamicpituitary gonadal axis in human males. J Clin Endocrinol Metab 2005;90:6609-6615.

-11 Chan YM, Butler JP, Pinnell NE, Pralong FP, Crowley WF Jr, Ren C, Chan KK, Seminara SB: Kisspeptin resets the hypothalamic GnRH clock in men. J Clin Endocrinol Metab 2011; 96:E908-E915.

12 George JT, Veldhuis JD, Roseweir AK, Newton CL, Faccenda E, Millar RP, Anderson RA: Kisspeptin-10 is a potent stimulator of $\mathrm{LH}$ and increases pulse frequency in men. J Clin Endocrinol Metab 2011;96:E1228-E1236.

13 Messager S, Chatzidaki EE, Ma D, Hendrick AG, Zahn D, Dixon J, Thresher RR, Malinge I, Lomet D, Carlton MB, Colledge WH, Caraty A, Aparicio SA: Kisspeptin directly stimulates gonadotropin-releasing hormone release via $G$ protein-coupled receptor 54 . Proc Natl Acad Sci USA 2005;102:1761-1766.
14 Han SK, Gottsch ML, Lee KJ, Popa SM, Smith JT, Jakawich SK, Clifton DK, Steiner RA, Herbison AE: Activation of gonadotropin-releasing hormone neurons by kisspeptin as a neuroendocrine switch for the onset of puberty. J Neurosci 2005;25:11349-11356

15 Irwig MS, Fraley GS, Smith JT, Acohido BV, Popa SM, Cunningham MJ, Gottsch ML, Clifton DK, Steiner RA: Kisspeptin activation of gonadotropin releasing hormone neurons and regulation of KiSS-1 mRNA in the male rats. Neuroendocrinology 2004;80:264-272.

16 Smith JT, Cunningham MJ, Rissman EF, Clifton DK, Steiner RA: Regulation of Kiss 1 gene expression in the brain of the female mouse. Endocrinology 2005;146:3686-3692.

17 Smith JT, Dungan HM, Stoll EA, Gottsch ML, Braun RE, Eacker SM, Clifton DK, Steiner RA: Differential regulation of KiSS-1 mRNA expression by sex steroids in the brain of the male mouse. Endocrinology 2005;146:2976-2984.

18 Adachi S, Yamada S, Takatsu Y, Matsui H, Kinoshita M, Takase K, Sugiura H, Ohtaki T, Matsumoto $\mathrm{H}$, Uenoyama $\mathrm{Y}$, Tsukamura $\mathrm{H}$, Inoue $\mathrm{K}$, Maeda $\mathrm{K}$ : Involvement of anteroventral periventricular metastin/kisspeptin neurons in estrogen positive feedback action on luteinizing hormone release in female rats. J Reprod Dev 2007;53:367-378.

19 Kinoshita M, Tsukamura H, Adachi S, Matsui $\mathrm{H}$, Uenoyama Y, Iwata K, Yamada S, Inoue K, Ohtaki T, Matsumoto H, Maeda K: Involvement of central metastin in the regulation of preovulatory luteinizing hormone surge and estrous cyclicity in female rats. Endocrinology 2005;146:4431-4436.

20 Mittelman-Smith MA, Williams H, Krajewski-Hall SJ, Lai J, Ciofi P, McMullen NT, Rance NE: Arcuate kisspeptin/neurokinin B/dynorphin (KNDy) neurons mediate the estrogen suppression of gonadotropin secretion and body weight. Endocrinology 2012;153:28002812. 
-21 Ohkura S, Takase K, Matsuyama S, Mogi K, Ichimaru T, Wakabayashi Y, Uenoyama Y, Mori Y, Steiner RA, Tsukamura H, Maeda KI, Okamura H: Gonadotrophin-releasing hormone pulse generator activity in the hypothalamus of the goat. J Neuroendocrinol 2009; 21:813-821.

-22 Wakabayashi Y, Yamamura T, Sakamoto K, Mori Y, Okamura H: Electrophysiological and morphological evidence for synchronized GnRH pulse generator activity among Kisspeptin/neurokinin B/dynorphin A (KNDy) neurons in goats. J Reprod Dev 2013;59:40-48.

23 Li XF, Kinsey-Jones JS, Cheng Y, Knox AM, Lin Y, Petrou NA, Roseweir A, Lightman SL, Milligan SR, Millar RP, O’Byrne KT: Kisspeptin signaling in the hypothalamic arcuate nucleus regulates $\mathrm{GnRH}$ pulse generator frequency in the rat. PLoS One 2009;4:e8334.

-24 Keen KL, Wegner FH, Bloom SR, Ghatei MA, Terasawa E: An increase in kisspeptin-54 release occurs with the pubertal increase in luteinizing hormone-releasing hormone-1 release in the stalk-median eminence of female rhesus monkeys in vivo. Endocrinology 2008; 149:4151-4157.

-25 Pineda R, Garcia-Galiano D, Roseweir A, Romero M, Sanchez-Garrido MA, Ruiz-Pino F, Morgan K, Pinilla L, Millar RP, Tena-Sempere M: Critical roles of kisspeptins in female puberty and preovulatory gonadotropin surges as revealed by a novel antagonist. Endocrinology 2010;151:722-730.

26 Hrabovszky E: Neuroanatomy of the Human Hypothalamic Kisspeptin System. Neuroendocrinology DOI: 10.1159/000356903.

27 Oakley AE, Clifton DK, Steiner RA: Kisspeptin signaling in the brain. Endocr Rev 2009;30:713-743.

-28 d'Anglemont de Tassigny X, Fagg LA, Carlton $\mathrm{MB}$, Colledge WH: Kisspeptin can stimulate gonadotropin-releasing hormone $(\mathrm{GnRH})$ release by a direct action at GnRH nerve terminals. Endocrinology 2008;149:3926-3932.

29 Ramaswamy S, Guerriero KA, Gibbs RB, Plant TM: Structural interactions between kisspeptin and GnRH neurons in the mediobasal hypothalamus of the male rhesus monkey (Macaca mulatta) as revealed by double immunofluorescence and confocal microscopy. Endocrinology 2008; 149:43874395.

- 30 Herde MK, Geist K, Campbell RE, Herbison AE: Gonadotropin-releasing hormone neurons extend complex highly branched dendritic trees outside the blood-brain barrier. Endocrinology 2011;152:3832-3841.

- 31 Asami T, Nishizawa N, Ishibashi Y, Nishibori K, Horikoshi Y, Matsumoto H, Ohtaki T, Kitada C: Trypsin resistance of a decapeptide KISS1R agonist containing an $\mathrm{N}^{\omega}$ methylarginine substitution. Bioorg Med Chem Lett 2012;22:6328-6332.

-32 Kuohung W, Burnett M, Mukhtyar D, Schuman E, Ni J, Crowley WF, Glicksman MA, Kaiser UB: A high-throughput smallmolecule ligand screen targeted to agonists and antagonists of the G-protein-coupled receptor GPR54. J Biomol Screen 2010;15:508517.

33 Asami T, Nishizawa N, Ishibashi Y, Nishibori K, Nakayama M, Horikoshi Y, Matsumoto S, Yamaguchi M, Matsumoto H, Tarui N, Ohtaki T, Kitada C: Serum stability of selected decapeptide agonists of KISS1R using pseudopeptides. Bioorg Med Chem Lett 2012;22: 6391-6396.

34 Tomita K, Oishi S, Ohno H, Peiper SC, Fujii $\mathrm{N}$ : Development of novel G-protein-coupled receptor 54 agonists with resistance to degradation by matrix metalloproteinase. J Med Chem 2008;51:7645-7649.

35 Asami T, Nishizawa N, Matsui H, Nishibori K, Ishibashi Y, Horikoshi Y, Nakayama M, Matsumoto SI, Tarui N, Yamaguchi M, Matsumoto H, Ohtaki T, Kitada C: Design, synthesis, and biological evaluation of novel investigational nonapeptide KISS1R agonists with testosterone-suppressive activity. J Med Chem 2013;56:8298-8307.

36 Paik WK, Kim S: Protein methylase I. Purification and properties of the enzyme. J Biol Chem 1968;243:2108-2114.

37 Mosberg HI, Hurst R, Hruby VJ, Gee K, Yamamura HI, Galligan JJ, Burks TF: Bis-penicillamine enkephalins possess highly improved specificity toward $\delta$-opioid receptors. Proc Natl Acad Sci USA 1983;80:5871-5874.

38 Dooley CT, Chung NN, Wilkes BC, Schiller PW, Bidlack JM, Pasternak GW, Houghten RA: An all D-amino acid opioid peptide with central analgesic activity from a combinatorial library. Science 1994;266:2019-2022.

39 Lee HJ, Ahn IA, Ro S, Choi KH, Choi YS, Lee $\mathrm{KB}$ : Role of azaamino acid residue in $\beta$-turn formation and stability in designed peptide. J Pept Res 2000;56:35-46.

40 Lee HJ, Choi KH, Ahn IA, Ro S, Jang HG, Choi YS, Lee KB: The $\beta$-turn preferential solution conformation of a tetrapeptide containing an azaamino acid residue. J Mol Struct 2001;569:43-54.

41 Thormann M, Hofmann HJ: Conformational properties of azapeptides. J Mol Struct 1999; 469:63-76.

42 Scott G, Ahmad I, Howard K, MacLean D, Oliva C, Warrington S, Wilbraham D, Worthington P: Double-blind, randomized, placebo-controlled study of safety, tolerability, pharmacokinetics and pharmacodynamics of TAK-683, an investigational metastin analogue in healthy men. Br J Clin Pharmacol 2013;75:381-391.

43 George JT, Millar RP, Anderson RA: Hypothesis: kisspeptin mediates male hypogonadism in obesity and type 2 diabetes. Neuroendocrinology 2010;91:302-307.

44 Dandona P, Dhindsa S: Update: hypogonadotropic hypogonadism in type 2 diabetes and obesity. J Clin Endocrinol Metab 2011;96: 2643-2651.

45 George JT, Veldhuis JD, Tena-Sempere M, Millar RP, Anderson RA: Exploring the pathophysiology of hypogonadism in men with type 2 diabetes: kisspeptin-10 stimulates serum testosterone and $\mathrm{LH}$ secretion in men with type 2 diabetes and mild biochemical hypogonadism. Clin Endocrinol (Oxf) 2013;79: 100-104.

46 Navarro VM, Fernandez-Fernandez R, Castellano JM, Roa J, Mayen A, Barreiro ML, Gaytan F, Aguilar E, Pinilla L, Dieguez C, Tena-Sempere M: Advanced vaginal opening and precocious activation of the reproductive axis by KiSS- 1 peptide, the endogenous ligand of GPR54. J Physiol 2004;561:379-386.

47 Smith JT, Acohido BV, Clifton DK, Steiner RA: KiSS-1 neurones are direct targets for leptin in the $o b / o b$ mouse. J Neuroendocrinol 2006;18:298-303.

48 Castellano JM, Navarro VM, FernandezFernandez R, Roa J, Vigo E, Pineda R, Dieguez C, Aguilar E, Pinilla L, Tena-Sempere M: Expression of hypothalamic KiSS-1 system and rescue of defective gonadotropic responses by kisspeptin in streptozotocin-induced diabetic male rats. Diabetes 2006;55: 2602-2610.

49 Dhillo WS, Chaudhri OB, Thompson EL, Murphy KG, Patterson M, Ramachandran R, Nijher GK, Amber V, Kokkinos A, Donaldson M, Ghatei MA, Bloom SR: Kisspeptin-54 stimulates gonadotropin release most potently during the preovulatory phase of the menstrual cycle in women. J Clin Endocrinol Metab 2007;92:3958-3966.

50 Chan YM, Butler JP, Sidhoum VF, Pinnell NE, Seminara SB: Kisspeptin administration to women: a window into endogenous kisspeptin secretion and $\mathrm{GnRH}$ responsiveness across the menstrual cycle. J Clin Endocrinol Metab 2012;97:E1458-E1467.

51 Jayasena CN, Nijher GM, Comninos AN, Abbara A, Januszewki A, Vaal ML, Sriskandarajah L, Murphy KG, Farzad Z, Ghatei MA, Bloom SR, Dhillo WS: The effects of kisspeptin-10 on reproductive hormone release show sexual dimorphism in humans. J Clin Endocrinol Metab 2011;96:E1963-E1972.

52 Jayasena CN, Comninos AN, Veldhuis JD, Misra S, Abbara A, Izzi-Engbeaya C, Donaldson M, Ghatei MA, Bloom SR, Dhillo WS: A single injection of kisspeptin-54 temporarily increases luteinizing hormone pulsatility in healthy women. Clin Endocrinol (Oxf) 2013; 79:558-563.

53 Roa J, Vigo E, Castellano JM, Navarro VM, Fernandez-Fernandez R, Casanueva FF, Dieguez C, Aguilar E, Pinilla L, Tena-Sempere M: Hypothalamic expression of KiSS-1 system and gonadotropin-releasing effects of kisspeptin in different reproductive states of the female rat. Endocrinology 2006;147:2864-2878.

54 George JT, Anderson RA, Millar RP: Kisspeptin-10 stimulation of gonadotrophin secretion in women is modulated by sex steroid feedback. Hum Reprod 2012;27:3552-3559.

55 Belchetz PE, Plant TM, Nakai Y, Keogh EJ, Knobil E: Hypophysial responses to continuous and intermittent delivery of hypothalamic gonadotropin-releasing hormone. Science 1978;202:631-633. 
56 Okada H, Heya T, Igari Y, Ogawa Y, Toguchi $\mathrm{H}$, Shimamoto T: One-month release injectable microspheres of leuprolide acetate inhibit steroidogenesis and genital organ growth in rats. Int J Pharm 1989;54:231-239.

57 Millar RP, Lu ZL, Pawson AJ, Flanagan CA, Morgan K, Maudsley SR: Gonadotropin-releasing hormone receptors. Endocr Rev 2004; 25:235-275.

58 Thompson EL, Murphy KG, Patterson M, Bewick GA, Stamp GW, Curtis AE, Cooke JH, Jethwa PH, Todd JF, Ghatei MA, Bloom SR: Chronic subcutaneous administration of kisspeptin-54 causes testicular degeneration in adult male rats. Am J Physiol Endocrinol Metab 2006;291:E1074-E1082.

-59 Seminara SB, Dipietro MJ, Ramaswamy S, Crowley WF Jr, Plant TM: Continuous human metastin 45-54 infusion desensitizes $\mathrm{G}$ protein-coupled receptor 54 -induced gonadotropin-releasing hormone release monitored indirectly in the juvenile male rhesus monkey (Macaca mulatta): a finding with therapeutic implications. Endocrinology 2006;147:2122-2126.

-60 Ramaswamy S, Seminara SB, Pohl CR, DiPietro MJ, Crowley WF Jr, Plant TM: Effect of continuous intravenous administration of human metastin 45-54 on the neuroendocrine activity of the hypothalamic-pituitarytesticular axis in the adult male rhesus monkey (Macaca mulatta). Endocrinology 2007; 148:3364-3370.

61 Jayasena CN, Nijher GM, Chaudhri OB, Murphy KG, Ranger A, Lim A, Patel D, Mehta A, Todd C, Ramachandran R, Salem V, Stamp GW, Donaldson M, Ghatei MA, Bloom SR, Dhillo WS: Subcutaneous injection of kisspeptin-54 acutely stimulates gonadotropin secretion in women with hypothalamic amenorrhea, but chronic administration causes tachyphylaxis. J Clin Endocrinol Metab 2009;94: 4315-4323.

62 Jayasena CN, Nijher GM, Abbara A, Murphy KG, Lim A, Patel D, Mehta A, Todd C, Donaldson M, Trew GH, Ghatei MA, Bloom SR, Dhillo WS: Twice-weekly administration of kisspeptin-54 for 8 weeks stimulates release of reproductive hormones in women with hypothalamic amenorrhea. Clin Pharmacol Ther 2010;88:840-847.

63 Matsui H, Tanaka A, Yokoyama K, Takatsu Y, Ishikawa K, Asami T, Nishizawa N, Suzuki A, Kumano S, Terada M, Kusaka M, Kitada C, Ohtaki T: Chronic administration of the metastin/kisspeptin analog KISS1-305 or the investigational agent TAK-448 suppresses hypothalamic pituitary gonadal function and depletes plasma testosterone in adult male rats. Endocrinology 2012;153:5297-5308.

-64 Tanaka A, Matsui H, Asami T, Nishizawa N, Kitada C, Ohtaki T, MacLean D, Kusaka M: Suppression of testosterone release by chronic administration of investigational novel metastin analogues in male dogs and monkeys, and in healthy male volunteers. Eur J Cancer Suppl 2010;8:7.
65 MacLean DB, Matsui H, Suri A, Neuwirth R, Colombel M: The investigational kisspeptin/ GPR54 agonist peptide analog, TAK-448, given as single-dose then 13-day continuous subcutaneous infusion, stimulates then suppresses the LH-testosterone axis in healthy male volunteers. Endocr Rev Abstr 2013;34:323.

66 Jayasena CN, Comninos AN, Nijher GM, Abbara A, De Silva A, Veldhuis JD, Ratnasabapathy R, Izzi-Engbeaya C, Lim A, Patel DA, Ghatei MA, Bloom SR, Dhillo WS: Twice-daily subcutaneous injection of kisspeptin-54 does not abolish menstrual cyclicity in healthy female volunteers. J Clin Endocrinol Metab 2013;98:4464-4474.

67 Ohkura S, Tanaka T, Kuroiwa T, Wakabayashi Y, Ohtaki T, Kusaka M, Okamura H: Effects of metastin/kisspeptin analog, TAK683 , on luteinizing hormone secretion in peripheral plasma, and gonadotropin-releasing hormone secretion in the pituitary portal circulation in goats. Endocr Rev Abstr 2011;32:3.

68 Wakabayashi Y, Yamamura T, Ohkura S, Tanaka T, Kusaka M, Okamura H: Effects of chronic administration of a metastin analog, TAK-683, on the GnRH pulse generator activity in ovariectomized goats. Endocrine Rev Abstr 2011;32:P2-P264.

69 Bianco SD, Vandepas L, Correa-Medina M, Gereben B, Mukherjee A, Kuohung W, Carroll R, Teles MG, Latronico AC, Kaiser UB: KISS1R intracellular trafficking and degradation: effect of the Arg386Pro disease-associated mutation. Endocrinology 2011;152:16161626.

70 Millar RP, Newton CL, Roseweir AK: Neuroendocrine GPCR signaling; in Fink G, Pfaff D, Levine J (eds): Handbook of Neuroendocrinology. New York, Elsevier, 2012, part 1, pp 21-53.

71 Navarro VM, Castellano JM, Fernandez-Fernandez R, Barreiro ML, Roa J, Sanchez-Criado JE, Aguilar E, Dieguez C, Pinilla L, Tena-Sempere M: Developmental and hormonally regulated messenger ribonucleic acid expression of KiSS- 1 and its putative receptor, GPR54, in rat hypothalamus and potent luteinizing hormone-releasing activity of KiSS-1 peptide. Endocrinology 2004;145:4565-4574.

72 Steiner RA, Bremner WJ, Clifton DK: Regulation of luteinizing hormone pulse frequency and amplitude by testosterone in the adult male rat. Endocrinology 1982;111:2055-2061.

73 Jackson GL, Kuehl D, Rhim TJ: Testosterone inhibits gonadotropin-releasing hormone pulse frequency in the male sheep. Biol Reprod 1991;45:188-194.

74 Lindzey J, Wetsel WC, Couse JF, Stoker T, Cooper R, Korach KS: Effects of castration and chronic steroid treatments on hypothalamic gonadotropin-releasing hormone content and pituitary gonadotropins in male wild-type and estrogen receptor-alpha knockout mice. Endocrinology 1998;139:4092-4101.

75 Bianco SD, Vandepas L, Correa-Medina M, Gereben B, Mukherjee A, Kuohung W, Car- roll R, Teles MG, Latronico AC, Kaiser UB: KISS1R intracellular trafficking and degradation: effect of the Arg386Pro disease-associated mutation. Endocrinology 2011;152:16161626.

76 Babwah AV, Pampillo M, Min L, Kaiser UB, Bhattacharya M: Single-cell analyses reveal that KISS1R-expressing cells undergo sustained kisspeptin-induced signaling that is dependent upon an influx of extracellular $\mathrm{Ca}^{2+}$. Endocrinology 2012;153:5875-5887.

$\checkmark 77$ Chan YM, Broder-Fingert S, Wong KM, Seminara SB: Kisspeptin/Gpr54-independent gonadotrophin-releasing hormone activity in Kiss1 and Gpr54 mutant mice. J Neuroendocrinol 2009;21:1015-1023.

78 Roseweir AK, Kauffman AS, Smith JT, Guerriero KA, Morgan $\mathrm{K}$, Pielecka-Fortuna J, Pineda R, Gottsch ML, Tena-Sempere M, Moenter SM, Terasawa E, Clarke IJ, Steiner RA, Millar RP: Discovery of potent kisspeptin antagonists delineate physiological mechanisms of gonadotropin regulation. J Neurosci 2009;29:3920-3929.

79 Roseweir AK, Millar RP: Kisspeptin antagonists. Adv Exp Med Biol 2013;784:159-186.

-80 Niida A, Wang Z, Tomita K, Oishi S, Tamamura H, Otaka A, Navenot JM, Broach JR, Peiper SC, Fujii N: Design and synthesis of downsized metastin (45-54) analogs with maintenance of high GPR54 agonistic activity. Bioorg Med Chem Lett 2006;16:134-137.

81 Guerriero KA, Keen KL, Millar RP, Terasawa E: Developmental changes in $\mathrm{GnRH}$ release in response to kisspeptin agonist and antagonist in female rhesus monkeys (Macaca mulatta): implication for the mechanism of puberty. Endocrinology 2012;153:825-836.

82 Kobayashi T, Sasaki S, Tomita N, Fukui S, Nakayama M, Kiba A, Kusaka M, Matsumoto S, Yamaguchi M, Itoh F, Baba A: 2-acylamino-4,6-diphenylpyridine derivatives as novel GPR54 antagonists with good brain exposure and in vivo efficacy for plasma LH level in male rats. Bioorg Med Chem 2010;18:5157-5171.

83 Kobayashi T, Sasaki S, Tomita N, Fukui S, Kuroda N, Nakayama M, Kiba A, Takatsu Y, Ohtaki T, Itoh F, Baba A: Synthesis and structure-activity relationships of 2-acylamino-4,6-diphenylpyridine derivatives as novel antagonists of GPR54. Bioorg Med Chem 2010;18:3841-3859.

84 Tanaka T, Ohkura S, Wakabayashi Y, Kuroiwa T, Nagai K, Endo N, Tanaka A, Matsui H, Kusaka M, Okamura H: Differential effects of continuous exposure to the investigational metastin/kisspeptin analog TAK-683 on pulsatile and surge mode secretion of luteinizing hormone in ovariectomized goats. J Reprod Dev 2013;59:563-568.

85 Goodman RL, Lehman MN, Smith JT, Coolen LM, de Oliveira CV, Jafarzadehshirazi MR, Pereira A, Iqbal J, Caraty A, Ciofi P, Clarke IJ: Kisspeptin neurons in the arcuate nucleus of the ewe express both dynorphin A and neurokinin B. Endocrinology 2007;148: 5752-5760.
Manipulation of the HPG Axis Using

Kisspeptin and its Analogs
Neuroendocrinology 2014;99:49-60 DOI: $10.1159 / 000357809$ 
86 Lehman MN, Coolen LM, Goodman RL: Minireview: kisspeptin/neurokinin B/dynorphin (KNDy) cells of the arcuate nucleus: a central node in the control of gonadotropinreleasing hormone secretion. Endocrinology 2010;151:3479-3489.

87 Okamura H, Tsukamura H, Ohkura S, Uenoyama Y, Wakabayashi Y, Maeda K: Kisspeptin and GnRH pulse generation. Adv Exp Med Biol 2013;784:297-323.

88 Lehman MN, Hileman SM, Goodman RL: Neuroanatomy of the kisspeptin signaling system in mammals: comparative and developmental aspects. Adv Exp Med Biol 2013; 784:27-62.

89 Navarro VM, Gottsch ML, Chavkin C, Okamura H, Clifton DK, Steiner RA: Regulation of gonadotropin-releasing hormone secretion by kisspeptin/dynorphin/neurokinin B neurons in the arcuate nucleus of the mouse. J Neurosci 2009;29:11859-11866.

90 Ruka KA, Burger LL, Moenter SM: Regulation of arcuate neurons coexpressing kisspeptin, neurokinin $B$, and dynorphin by modulators of neurokinin 3 and $\kappa$-opioid receptors in adult male mice. Endocrinology 2013; 154:2761-2771.

91 Grachev P, Millar RP, O’Byrne KT: The Role of Neurokinin B Signalling in Reproductive Neuroendocrinology. Neuroendocrinology DOI: $10.1159 / 000357734$.

92 Goodman RL, Coolen LM, Lehman MN: A Role for Neurokinin B in Pulsatile GnRH Secretion in the Ewe. Neuroendocrinology DOI: 10.1159/000355285.

-93 Amstalden M, Coolen LM, Hemmerle AM, Billings HJ, Connors JM, Goodman RL, Lehman $\mathrm{MN}$ : Neurokinin 3 receptor immunoreactivity in the septal region, preoptic area and hypothalamus of the female sheep: colocalisation in neurokinin B cells of the arcuate nucleus but not in gonadotrophin-releasing hormone neurones. J Neuroendocrinol 2010;22:1-12.

94 Herbison AE, de Tassigny Xd, Doran J, Colledge WH: Distribution and postnatal development of Gpr54 gene expression in mouse brain and gonadotropin-releasing hormone neurons. Endocrinology 2010;151:312-321.
95 Kinsey-Jones JS, Li XF, Luckman SM, O’Byrne KT: Effects of kisspeptin-10 on the electrophysiological manifestation of gonadotropinreleasing hormone pulse generator activity in the female rat. Endocrinology 2008;149:10041008.

96 Navarro VM, Gottsch ML, Wu M, GarciaGaliano D, Hobbs SJ, Bosch MA, Pinilla L, Clifton DK, Dearth A, Ronnekleiv OK, Braun RE, Palmiter RD, Tena-Sempere M, Alreja M, Steiner RA: Regulation of NKB pathways and their roles in the control of Kiss1 neurons in the arcuate nucleus of the male mouse. Endocrinology 2011;152:42654275.

97 Sannella MI, Petersen SL: Dual label in situ hybridization studies provide evidence that luteinizing hormone-releasing hormone neurons do not synthesize messenger ribonucleic acid for $\mu, \kappa$, or $\delta$ opiate receptors. Endocrinology 1997;138:1667-1672.

98 Mitchell V, Prevot V, Jennes L, Aubert JP, Croix D, Beauvillain JC: Presence of mu and kappa opioid receptor mRNAs in galanin but not in GnRH neurons in the female rat. Neuroreport 1997;8:3167-3172.

-99 Topaloglu AK, Reimann F, Guclu M, Yalin AS, Kotan LD, Porter KM, Serin A, Mungan NO, Cook JR, Ozbek MN, Imamoglu S, Akalin NS, Yuksel B, O'Rahilly S, Semple RK: TAC3 and TACR3 mutations in familial hypogonadotropic hypogonadism reveal a key role for Neurokinin B in the central control of reproduction. Nat Genet 2009;41:354358.

100 Topaloglu AK, Tello JA, Kotan LD, Ozbek MN, Yilmaz MB, Erdogan S, Gurbuz F, Temiz F, Millar RP, Yuksel B: Inactivating KISS1 mutation and hypogonadotropic hypogonadism. N Engl J Med 2012;366:629635.

101 Silveira LG, Noel SD, Silveira-Neto AP, Abreu AP, Brito VN, Santos MG, Bianco SD, Kuohung W, Xu S, Gryngarten M, Escobar ME, Arnhold IJ, Mendonca BB, Kaiser UB, Latronico AC: Mutations of the KISS1 gene in disorders of puberty. J Clin Endocrinol Metab 2010;95:2276-2280.
02 Teles MG, Bianco SD, Brito VN, Trarbach EB, Kuohung W, Xu S, Seminara SB, Mendonca BB, Kaiser UB, Latronico AC: A GPR54-activating mutation in a patient with central precocious puberty. $\mathrm{N}$ Engl J Med 2008;358:709-715.

03 Wakabayashi Y, Nakada T, Murata K, Ohkura S, Mogi K, Navarro VM, Clifton DK, Mori Y, Tsukamura H, Maeda K, Steiner RA, Okamura H: Neurokinin B and dynorphin A in kisspeptin neurons of the arcuate nucleus participate in generation of periodic oscillation of neural activity driving pulsatile gonadotropin-releasing hormone secretion in the goat. J Neurosci 2010;30: 3124-3132.

104 Navarro VM, Castellano JM, McConkey SM, Pineda R, Ruiz-Pino F, Pinilla L, Clifton DK, Tena-Sempere M, Steiner RA: Interactions between kisspeptin and neurokinin $\mathrm{B}$ in the control of GnRH secretion in the female rat. Am J Physiol Endocrinol Metab 2011;300:E202-E210.

105 de Croft S, Boehm U, Herbison AE: Neurokinin $B$ activates arcuate kisspeptin neurons through multiple tachykinin receptors in the male mouse. Endocrinology 2013;154:27502760.

106 Sandoval-Guzman T, Rance NE: Central injection of senktide, an NK3 receptor agonist, or neuropeptide $\mathrm{Y}$ inhibits LH secretion and induces different patterns of Fos expression in the rat hypothalamus. Brain Res 2004; 1026:307-312.

107 Grachev P, Li XF, Kinsey-Jones JS, di Domenico AL, Millar RP, Lightman SL, O’Byrne KT: Suppression of the GnRH pulse generator by neurokinin B involves a $\kappa$-opioid receptor-dependent mechanism. Endocrinology 2012;153:4894-4904.

108 Mittelman-Smith MA, Williams H, Krajewski-Hall SJ, McMullen NT, Rance NE: Role for kisspeptin/neurokinin B/dynorphin (KNDy) neurons in cutaneous vasodilatation and the estrogen modulation of body temperature. Proc Natl Acad Sci USA 2012; 109:19846-19851. 